\title{
W/O マイクロエマルションを利用する炭酸バリウム微粒子の調製
}

\author{
（1983 年 11 月 7 日受理） \\ 今野紀二郎* . 小出 操 - 北原文雄
}

\begin{abstract}
$\mathrm{W} / \mathrm{O}$ マイクロエマルション相を利用して超微粒子を調製する目的で，ポリ(オキシェチレン) 型非イ オン活性剤 $/ \mathrm{Ba}(\mathrm{OH})_{2}$ 水溶液/シクロヘキサンまたはイソオクタン系に種々の条件下で $\mathrm{CO}_{2}$ を吹き込 むことによって $\mathrm{BaCO}_{3}$ 微粒子の調製を行なった。活性剤に対する水のモル比を変えて生成した粒子の 大きさおよび形状は, $\mathrm{Ba}(\mathrm{OH})_{2}$ 水溶液の可溶化溶液が無色透明から青色透明溶液へ相転移する領域で いらじるしく変化した。すなわち，前者では軸比がおよそ 23〜39 の棒状粒子が生成し，後者では単分 散性の棈円球状粒子が生成し, 相転移領域では棒状と楕円球状の混合粒子が生成した。この変化は動的 光散乱法による可溶化溶夜の測定から W/O マイクロエマルション相の形成と関連していることがわか った。また W/O マイクロエマルション相で生成する粒子の大きさは, その相中の Water pool の大き さによってコントロールされた。この事実は，また実験的に $\mathrm{Ba}(\mathrm{OH})_{2}$ 濃度㘧よび温度を变えることに よって調製した粒子の大きさおよび形状の変化から確かめることができた。一方，粒子の生成拉よび成 長過程を $\mathrm{CO}_{2}$ の吹き込み量を変えて調べた結果, 逆ミセル相と W/O マイクロエマルション相では異 なった。
\end{abstract}

\section{1 鍺 言}

界面活性剂が炭化水素夜体中で形成する逆ミセルは多量の水を 可溶化する能力を有するが, 可溶化量の少ない系では水は逆ミ七 ル内の極性基部と結合し1，ミセル量はとれ的ど增加しない2。 しかし, 可溶化量が増大するにつれて, ミセル量は急激に增加 し2), Water pool を内蔵した逆ミセル, いわゆるW/O マイクロ エマルション相を形成する2)。このように, 界面活性剂/水/炭

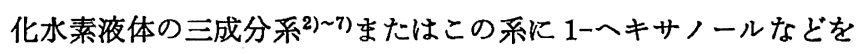
含む四成分系8 ${ }^{822)}$ からなる W/O マイクロエマルション相は,

東京理科大学工学部工業化学科・界面科学研究所, 162 東 京都新宿区神楽坂

1) A. Kitahara, K. Watanabe, K. Kon-no, T. Ishikawa, J. Colloid Interface Sci., 29, 15(1969) ; K. Kon-no, A. Kitahara, ibid., 35, 409(1971).

2) H. F. Eicke, J. Rehak, Helv. Chim. Acta, 59, 2883 (1976).

3) M. Zulauf, H. F. Eicke, J. Phys. Chem., 83, 480 (1979).

4) R. A. Day, B. H. Robinson, J. H. R. Clarke, J. V. Doherty, J. Chem. Soc., Faraday Trans. 1, 75, 132 (1979).

5) E. Sein, J. R. Lalanne, J. Colloid Interface Sci., 72, 363(1979).

6) P.E. Zinsli, J. Phys. Chem., 83, 3223(1979).

7) E. Gulari, B. Bedwell, S. Alkhafji, J. Colloid Interface Sci., 77, 202(1980).

8) P. Ekwall, L. Mandell, K. Fontell, ibid., 33, 215 (1970).

9) C. Kumar, D. Balasubramanian, ibid., 69, 271(1979); 74, 64(1980); J. Phys. Chem., 84, 1895(1980).
Water pool の高分散系で，非常に大きな油水界面を有し，熱力 学的に安定な溶液である。構造的には，この Water pool 上に活

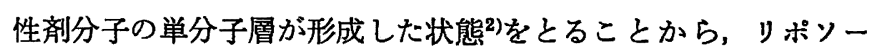
ムのそれと類似している。

したがって, W/O マイクロエマルションは生体膜や酵素反応の モデル系として注目されるようになり，Water pool の極性 ${ }^{18) 14)}$,

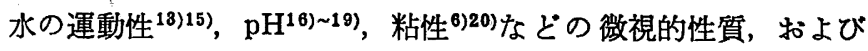
Water pool 中に拈けるイミダゾール，アルキルアミンなどの低 分子量の触媒分子 ${ }^{21) 22)}$ や酵素分子(16)28) 26)による脂肪酸エステル

10) A. M. Cazabat, D. Langerin, A. Pouchelon, J.Colloid Interface Sci., 73, 1(1980).

11) J.Sjöblom, K. Rosengrist, P. Stenius, Colloid Polym. Sci., 260, 82(1982).

12) D. J. Cebula, D. Y. Myers, R. H. Ottewill, ibid., 260, 96(1982).

13) F. M. Menger, G. Saito, G. V. Sanzero, J. R. Dodd, J. Am. Chem. Soc., 97, 909(1975).

14) M. Wong, J. K. Thomas, M. Grätzel, ibid., 98, 2391 (1976).

15) M. Wong, J.K. Thomas, J. Nowak, ibid., 99, 4730 (1977).

16) F. M. Menger, K. Yamada, ibid., 97, 909(1979).

17) I. Fujii, I. Kawai, H. Nishikawa, Bull, Chem. Soc. Jpn., 52, 2051(1979).

18) R.E.Smith, P. L. Luisi, Helv. Chim. Acta, 63, 2302 (1980).

19) O.A.EI Seoud, A. M. Chinelatto, M. R. Shimizu, $J$. Colloid Interface Sci., 88, 420(1982).

20) E. Keh, B. Valeur, ibid., 79, 465(1981).

21) F. M. Menger, F. A. Donohue, R. F. Williams, J. Am, Chem, Soc., 95, 286(1973). 
などの加水分解反応などの研究がさかんに行なわれてきた。

一方, W/O マイクロエマルションの Water pool の活動度は 1 に近いため, 電解質のような水溶性物質を溶解することが可能 である。したがって，この特異な環境下にあるWater pool に電 解質や水溶性高分子モノマーを溶解させ, 沈殿反応, 還元反応, 重合反応などを行なった場合, 生成する沈殿物やポリマー粒子の 大きさは，微細な Water pool の大きさにコントロールされるこ とが期待できるので，W/O マイクロエマルションを利用して超 微細なコロイド粒子を調製することができよう。また粒子の生成 と同時に W/O マイクロエマルションを形成する活性剂分子が粒 子上に吸着する可能性があるので，安定性のよいコロイド分散系 を調製することもできよう。

W/O マイクロエマルションを利用して超微粒子を調製する試

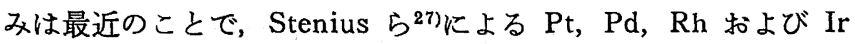
粒子の調製を始め, Nagy ら $\left.{ }^{28}\right)$ にる $\mathrm{NiB}, \mathrm{FeB}$ 粒子の調製が行

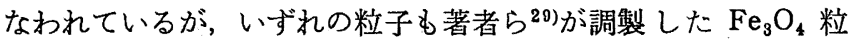
子と同様に直径 30 〜 $50 \AA$ の単分散性のよい球状粒子であった。 また最近になって, Fendler ら゙0)による直径がおよそ $150 \AA ̊ 丿$ の比 較的単分散性な $\mathrm{Au}$ 粒子の調製が報告された。とくに著者ら ${ }^{29}$ によって得られた $\mathrm{Fe}_{3} \mathrm{O}_{4}$ の分散系は磁性流体として取り扱らこ

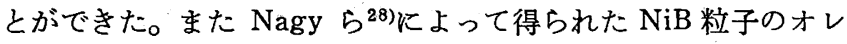
フィンの水素化反応に対する触媒効率は Raney ニッヶル触媒の それと同程度であった。

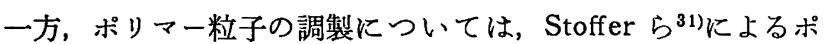

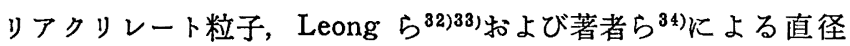
$500 \AA ̊$ 以下のポリアクリルアミド粒子のみである。

このように W/O マイクロエマルションを利用すると超微粒子 が得られるが，逆ミ七ル溶液に怙ける触媒反応の場合にみられる ように生成物を系から単離することばかりでなく，その分散系を

22）今野紀二郎, 勝田正美, 中村顕二, 森 貞光, 北原文雄, 日化, 1980，435.

23) P. Douzou, E. Keh, C. Balny, Proc. Natl. Acad. Sci. U.S.A., 76, 681(1979).

24) S. Barbaric, P. L. Luisi, J.Am. Chem, Soc., 103, 4239 (1981).

25) C. Grandi, R. E. Smith, P. L. Luisi, J. Biol. Chem., 25, 837(1981).

26) K. Martinek, A. V. Levashov. Yu. L. Khmelnitsky, N. L. Klyachko, I. V. Berezin, Science, 218, 889(1982).

27) M. Boutonnet, J. Kizling, P.Stenius, Colloids Surfaces, 5, 209(1982).

28) J. B. Nagy, A. Gourgue, E. G. Deroune, Stud. Surf. Sci. Catal., 1982. Preparation of Catalysts, "Third International Symposium on Scientific Bases for the Preparation of Heterogeneous Catalysts", LouvanLa-Neuve, Sept. 1982 ; Elsevier:Amsterdam, (1982).

29) M. Gobe, K. Kon-no, K. Kandori, A. Kitahara, J. Colloid Interface Sci., 93, 293(1983).

30) K. Kurihara, J. Kizling, P.Stenius, J. H. Fendler, J. Am. Chem. Soc., 105, 2574(1983).

31) J. O.Stoffer, T. Bone, J. Polym. Sci., 18, 2641(1980).

32) Y.S. Leong, G. Riess, F. Candau, J. Chim. Phys., $78,279(1981)$.

33) Y.S. Leong, F. Candau, J. Phys, Chem., 86, 2269 (1982).

34）五辺正男, 今野紀二郎, 北原文雄, 第 35 回コロイドおよ び界面化学討論会詯演要旨集,（1982）p. 36.
精製することが困難であるように思われる。

そこで本研究では，たとえ生成する超微粒子の系からの単離が 困難であっても，その分散系の精製を必要としない超微粒子の調 製の試みの一つとして, 非イオン活性剤 $/ \mathrm{Ba}(\mathrm{OH})_{2}$ 水溶液/シク ロヘキサン括よびイソオクタン系に $\mathrm{CO}_{2}$ を吹き込むことによっ て $\mathrm{BaCO}_{3}$ 粒子の調製を行なった。そして粒子の生成過程や粒子 の大きさおよび形状に㧊よぼす Water pool の大きさ，活性剤お よび $\mathrm{Ba}(\mathrm{OH})_{2}$ 濃度, 調製温度および $\mathrm{CO}_{2}$ の吹き込み速度の効 果について調べた。

\section{2 実験}

\section{1 試 料}

界面活性剤は，ポリ(オキシェチレン)=ノニルフェニルニエーテ ル（平均オキシェチレン基数：4拈よび 6)（以下それぞれを NP-4 および NP-6 と略記する）の 2 種類を用いた。これらは既 報の方法 ${ }^{35)}$ にしたがって精製し，減圧下 $60^{\circ} \mathrm{C}$ で乾燥して用いた。 水酸化バリウムは市肘特級品を精製せずに用いた。水はイオン交 換水を蒸留したのち，窒素を十分通して用いた。溶媒は市肘特級 品であるシクロヘキサンおよびイソオクタンを蒸留して用いた。

\section{$2.2 \mathrm{Ba}(\mathbf{O H})_{2}$ 水溶液の可溶化測定}

活性剤油溶液における $\mathrm{Ba}(\mathrm{OH})_{2}$ 水溶液の可溶化測定は, 既報

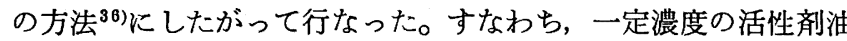
溶液の一定量を試験管に採取し，そこへ $\mathrm{Ba}(\mathrm{OH})_{2}$ 水溶液の量を 変えながら涯加し，アンプルを作成した。そして一定温度の水槽 中でふりまぜながら溶液の濁り度を肉眼で観察することによって 行なった。

\section{$2.3 \mathrm{BaCO}_{3}$ の調製法}

$\mathrm{BaCO}_{3}$ 粒子の調製は, 一定濃度の活性剂油溶液に種 々の濃度 の $\mathrm{Ba}(\mathrm{OH})_{2}$ 水溶液の所定量を一定温度の水槽中で可溶化したの ち, 30 分間静置し, $\mathrm{CO}_{2}$ をガラスフィルターを通して吹き込む ことによって行なった。反応の停止は， $\mathrm{CO}_{2}$ を吹き込んだのち， ただちに窒素を十分吹き込むことによって行なった。また比較の ために水中に打いても $\mathrm{BaCO}_{3}$ 粒子を調製した。なお， $\mathrm{BaCO}_{3}$ の 生成率は，つぎのようにして求めた。すなわち，活性剤油溶液お。 よび水中で調製した分散液にエタノールおよび水を加党, $\mathrm{BaCO}_{3}$ 粒子を遠心分離器で沈降させたのち，ふたたび溶媒を加えて洗浄 した。この沈降と洗浄の操作は，U.V.法で活性剂の存在が確認 できなくなるまでくり返し行なった。その後, 減圧下で乾燥し, 重量を测定して, 式( 1 )から算出した。

$$
\mathrm{BaCO}_{3} \text { の生成率 }=\frac{\mathrm{BaCO}_{3} / \mathrm{mol}}{\mathrm{Ba}(\mathrm{OH})_{2} / \mathrm{mol}} \times 100
$$

\section{$2.4 \mathrm{BaCO}_{3}$ の同定}

生成物の同定は，東芝(株)会社製 ADG-301 型X線装置を用い て行なった。図 1 には, 一例として $\mathrm{NP}-6 / \mathrm{Ba}(\mathrm{OH})_{2}$ 水溶液／シ クロヘキサンの $\mathrm{W} / \mathrm{O}$ マイクロエマルション系で得られた生成物 のX線回折図を示した。ここで縦軸は，2 $\theta=24.0^{\circ}$ に括ける回折 強度を 100 としたときの強度比を示す。図 1 からわかるように,

35) A. Kitahara, K. Kon-no, J. Phys, Chem., 70, 3394 (1966).

36) K. Kon-no, A. Kitahara, J. Colloid Interface Sci., 34, 221(1970). 


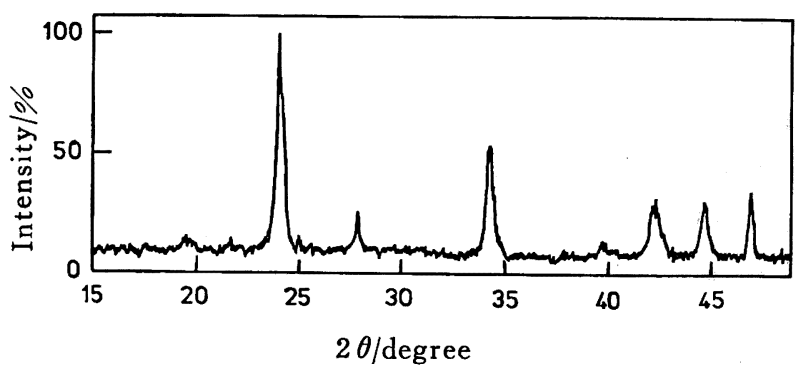

Fig. 1 X-ray diffraction pattern of $\mathrm{BaCO}_{3}$ prepared in W/O microemulsion of NP-6/cyclohexane systems

$R=72, \mathrm{pH}=7.0,\left[\mathrm{Ba}(\mathrm{OH})_{2}\right]=0.20 \mathrm{~mol} \cdot l^{-1}$

$R:$ Eexpresses molar ratio of water to surfactant.

回折ピークは $2 \theta=19.6^{\circ}, 24.0^{\circ}, 27.8^{\circ}, 34.2^{\circ}, 39.8^{\circ}, 42.2^{\circ}$, $44.8^{\circ}, 46.9^{\circ}$ に現われた。この眓は $\mathrm{BaCO}_{3}$ のX線回折図の $\mathrm{AS}$ $\mathrm{TM}$ カードを参照して, 生成物が $\mathrm{BaCO}_{3}$ であることを確認し た。同様な回折図は, また $\mathrm{NP}-4 / \mathrm{Ba}(\mathrm{OH})_{2}$ 水溶液/イソオクタ ン系で得られた生成物についても得られた。

\section{$2.5 \mathrm{BaCO}_{3}$ 粒子の形状および大ききの測定}

$\mathrm{BaCO}_{3}$ 粒子の形状および大きさの測定は, 日本電子(株)社製 電子顕微鏡 JEM-100B 型を用い，粒子を写真撮影し，その長軸 長，l，および短軸長， $s$ ，を測定することによって行なった。な お, 顕微鏡用試料は $\mathrm{BaCO}_{3}$ 分散液の少量をシートメッシュ(150 メッシュ）上に展開したホルムパール膜上に滴下し，風乾して作 成した。一方， $l$ および $s$ の平均值（以下それぞれを $\bar{l}$ および $\bar{s}$ と略記する）を用いて，式(2)，（3），(4)および(5)からそれ ぞれ $\mathrm{BaCO}_{3}$ 粒子の $1 \mathrm{~mol}$ の重量, すなわち粒子量, $M$, および 分散液 $1 \mathrm{~m} l$ 中の $\mathrm{BaCO}_{3}$ の粒子数， $N$, を算出した。

軸比 $>2$ の棒状粒子, $R$, について

$$
\begin{aligned}
& M=\pi \cdot\left(\frac{\bar{s}}{2}\right)^{2} \cdot \bar{l} \cdot \rho \cdot N_{\mathrm{A}} \\
& N=C_{0} \cdot W \cdot N_{\mathrm{A}} / M
\end{aligned}
$$

軸比 $<2$ の楕円球状粒子, $E$, について

$$
\begin{aligned}
& M=\frac{4}{3} \cdot \pi \cdot\left(\frac{\bar{s}}{2}\right)^{2} \cdot \frac{\bar{l}}{2} \cdot \rho \cdot N_{\mathrm{A}} \\
& N=C_{0} \cdot W \cdot N_{\mathrm{A}} / M
\end{aligned}
$$

ここで, $\rho: \mathrm{BaCO}_{3}$ の密度, $N_{\mathrm{A}}$ : Avogadro 数, $C_{0}$ : 活性剂油 溶液 $1 \mathrm{~m} l$ に可溶化した $\mathrm{Ba}(\mathrm{OH})_{2}$ のモル数, $W: \mathrm{BaCO}_{3}$ の分 子量である。

\section{3 結 果之考察}

\section{1 活性剤油溶液における $\mathrm{Ba}(\mathrm{OH})_{2}$ 水溶液の溶存状態}

$\mathrm{BaCO}_{3}$ 粒子の調製を $\mathrm{Ba}(\mathrm{OH})_{2}$ 水溶液の可溶化溶液で行なう ために, NP-6/シクロヘキサン系拈よび NP-4/“イソオクタン” 系における $0.2 \mathrm{~mol} \cdot l^{-1} \mathrm{Ba}(\mathrm{OH})_{2}$ 水溶液の溶存状態を調べた。 図 2 には，一例として NP-6/シクロヘキサン系における状態図 を示しだ。図 2 中の白丸および黒丸の通る曲線は，それぞれ $\mathrm{Ba}$ $(\mathrm{OH})_{2}$ 水溶液の可溶化曲線および活性剂 $/ \mathrm{Ba}(\mathrm{OH})_{2}$ 水溶液から なる錯体の溶解度曲線 ${ }^{36)}$ を示し，両曲線で囲まれた領域が可溶化 領域である。この領域は $20^{\circ} \mathrm{C}$ 付近で急激に増大し, 最大可溶化

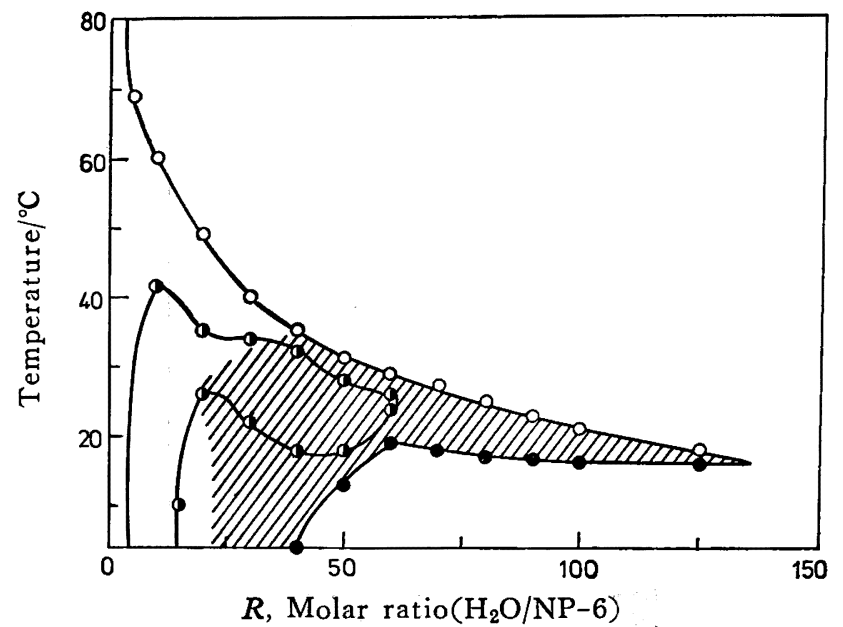

Fig. 2 Solubility diagram of $\mathrm{Ba}(\mathrm{OH})_{2}$ solution in NP6/cyclohexane system

Shadow region expresses blue translucent solution. $[\mathrm{NP}-6]=0.10 \mathrm{~mol} \cdot \mathrm{kg}^{-1},\left[\mathrm{Ba}(\mathrm{OH})_{2}\right]=0.20 \mathrm{~mol} \cdot \mathrm{l}^{-1}$

Table 1 Size and existing ratio of small and large reversed micelles of $\mathrm{NP}-6 / 0.20 \mathrm{~mol} \cdot l^{-1} \mathrm{Ba}(\mathrm{OH})_{2} /$ cyclohexane systems

\begin{tabular}{lrrrr}
$R^{a)}$ & $\overbrace{\text { Small }}^{\text {Diameter/A }}$ & Large & Small & Large \\
\hline 4.5 & 42 & 132 & 80 & 20 \\
9 & 1380 & 11800 & 90 & 10 \\
13.5 & 1290 & 9040 & 90 & 10 \\
18 & 1440 & 11400 & 90 & 10
\end{tabular}

a) $R$ : Molar ratio of $\mathrm{H}_{2} \mathrm{O}$ to NP-6.

量は $17^{\circ} \mathrm{C}$ で活性剂に対する水のモル比（以下 $R$ と略記する）で 135 であったが, 可溶化領域内には 6 時間のちに活性剤相と水相 に分離する領域（図 2 中の半白丸を通る曲線で囲まれた領域）が

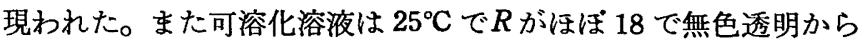
青色透明溶夜（図 2 中の斜線部分）へ変化した。一方, NP-6/イ ソオクタン系に打ける可溶化領域は NP-6/シクロへキサン系に くらべ小さく, しかも低温側へシフトし, 最大可溶化量は $-4^{\circ} \mathrm{C}$ において $R$ で 18 であった。また無色透明から青色透明溶液への 変化は $R$ が 10 付近でみられたが, 二相分離領域は現われなかっ た。

これら両系で観察された無色透明から青色透明溶液への変化は 水可溶化による逆ミセルの溶存状態に関連することから, 動的光 散乱法で逆ミセルの大きさを調べた。その結果, 青色透明溶液で は光の散乱が大きく测定できなかったが，無色透明溶液ではほぼ 球状の大きな逆ミセルと小さな逆ミセルの 2 種類が形成すること がわかった。表 1 にはそれぞれの逆ミセルの半径とその存在比を 示した。ここで無色透明溶液系で形成する逆ミ七ルは，分子溶解 している活性剂分子勇が水分子との水素結合によって親水性が增 して形成した逆ミセル38)で，その内部の水はかなり固定されてい る状態であると考えられる。一方，青色透明溶夜ではその系が光 を大きく散乱することから考光，W/O マイクロエマルション39

37）今野紀二郎，北原文焳，工化，68，2058(1965).

38) A. Kitahara, J. Phys. Chem., 67, 2788(1965), 


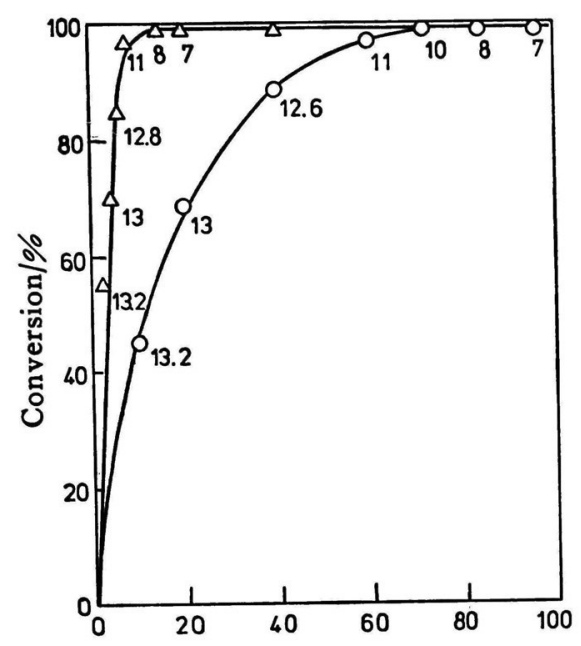

Amount of $\mathrm{CO}_{2}$ bubbled $/ \mathrm{m} l$

Fig. 3 The change of conversion of $\mathrm{BaCO}_{3}$ with amount of $\mathrm{CO}_{2}$ bubbled at $25^{\circ} \mathrm{C}$

$\mathrm{O}:$ Aqueous solution, $\left[\mathrm{Ba}(\mathrm{OH})_{2}\right]=0.20 \mathrm{~mol} \cdot \mathrm{l}^{-1}$

$\triangle:$ W/O microemulsion, $0.10 \mathrm{~mol} \cdot \mathrm{kg}^{-1} \mathrm{NP}-6 /$ cyclohexane systems, $R=72,\left[\mathrm{Ba}(\mathrm{OH})_{2}\right]=0.20 \mathrm{~mol} \cdot l^{-1}$
すなわち，Water pool を内蔵した逆ミセルが形成しているもの と考兄らる。

\section{$3.2 \mathrm{CO}_{2}$ の吹き込み量による $\mathrm{BaCO}_{3}$ の生成率と生成過程}

$\mathrm{BaCO}_{3}$ 粒子の生成条件を調べるま兄に, $\mathrm{CO}_{2}$ の吹き込み量に よる $\mathrm{BaCO}_{3}$ の生成率と生成過程の変化を $\mathrm{NP}-6 / 0.20 \mathrm{~mol} \cdot \mathrm{l}^{-1}$ $\mathrm{Ba}(\mathrm{OH})_{2} /$ シクロヘキサン系 $(R=4$ および 72$)$ で調べた。図 3 には, 一例として $R=72$ および水中に $\mathrm{CO}_{2}$ を吹き込み速度, 4 $\mathrm{ml} / \mathrm{min}$ で吹き込んだときの $\mathrm{CO}_{2}$ 量による $\mathrm{BaCO}_{3}$ の生成率の 変化を示した。図中の数字は $\mathrm{BaCO}_{3}$ 調製後の系の $\mathrm{pH}$ 值を示す。 図3から，W/O マイクロエマルションおよびバルク水の両相に おける生成率は, $\mathrm{CO}_{2}$ の吹さ込及量とともに增大し, 前者では 0.5 分, 後者では 4 分でほぼ $100 \%$ に達した。一方, $\mathrm{BaCO}_{3}$ の 生成速度は, 生成率一吹き达み量曲線の初期勾配から見積るとW/ ○、イクロエマルションの方がバルク水相よりほぼ 4 倍ほど速い ことがわかった。これは $\mathrm{CO}_{2}$ が活性剤によって保持される結果 によるものと考えられる。

一方, $\mathrm{BaCO}_{3}$ 粒子の生成過程は, 図 4 から最初粒子はある線 状物質の所々の場所に生成するが, $\mathrm{CO}_{2}$ の吹さ込み量が増加す るにつれて線状物質は針状へと变化し，それがある所で切断し，

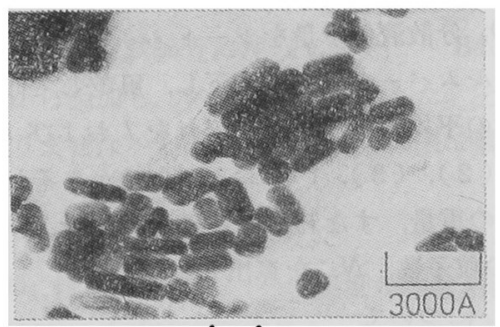

(d)

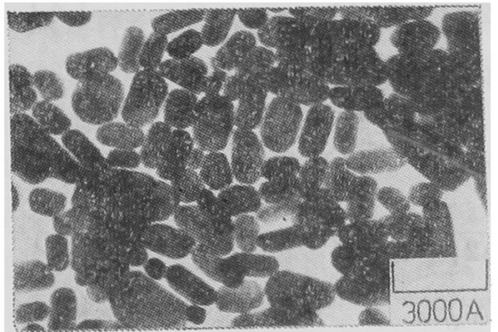

(e)

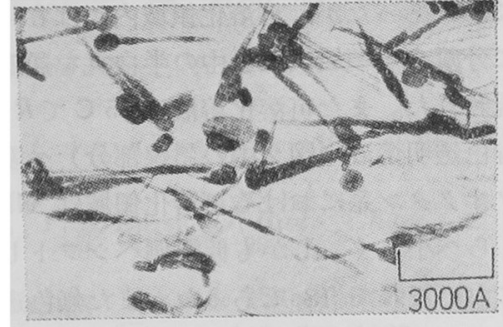

(b)

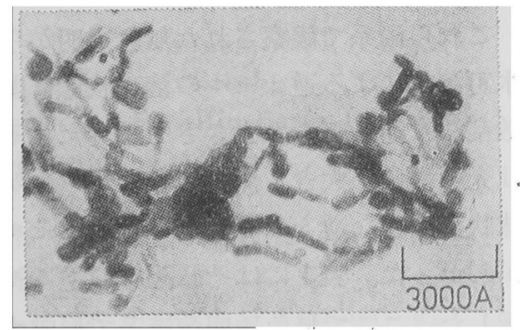

(c)

Fig. 4 Electron microngraphs of $\mathrm{BaCO}_{3}$ particles prepared with various amount of $\mathrm{CO}_{2}$ in $\mathrm{NP}-6 /$ cyclohexane systems at $25^{\circ} \mathrm{C}$

Amount of $\mathrm{CO}_{2}(\mathrm{ml}):$ (a) ; 2, (b) ; 4, (c) ; 8, (d) ; 9, e ) ; 10 $R=72,\left[\mathrm{Ba}(\mathrm{OH})_{2}\right]=0.20 \mathrm{~mol} \cdot l^{-1}[\mathrm{NP}-6]=0.10 \mathrm{~mol} \cdot \mathrm{kg}^{-1}$

39) J. H. Schulman, W. Stoeckenius, L. M. Prince, J. Phys. Chem., 63, 167(1959). 
その端に粒子が徐々に成長してゆくようすがわかる。しかし，さ らに $\mathrm{CO}_{2}$ を吹さ込み, 系の $\mathrm{pH}$ が 10 ぐらいになると, 針状物 質は消失し，粒子は楕円球状体となって，pH が7になるまで成 長しつつ゚けることがわかる。ここで図 4 (a)，(b)および (c) で観察される線状または針状物質は，現在明らかでないが， Ba $(\mathrm{OH})_{2}$ 水溶液の可溶化溶液を冷却して得られる物質の電子顕微 鏡写真が采状であること, そしてその物質が水に可溶であるばか りでなく，図 4 (d)では完全に消失すること，さらには非イオ ン活性剤（オキシェチレン基数：10）水溶液に $\mathrm{CaCl}_{2}$ を添加す ると, 単位オキシェチレン基あたり $3 \mathrm{CaCl}_{2} \cdot 15 \mathrm{H}_{2} \mathrm{O}$ 付加体の固
体分子化合物が生成 ${ }^{40)}$ 寸ることから考光て, $\mathrm{Ba}(\mathrm{OH})_{2} / \mathrm{CO}_{2} /$ 活性 剂の錯体ではないかと考えられる。

一方, $R$ の小さい系 $(R=4)$ では, $\mathrm{CO}_{2}$ の吹き込み量が小さいと きは $R=72$ の場合と同様に糸状錯体の生成が認められ，その所 々に非常に小さな粒子が生成したが，その成長過程は $R=72$ の 場合と違って, $\mathrm{CO}_{2}$ の吹き込み量の増加とともにほぼ一定の長 さに切断した糸状錯体上に沿って成長し，棒状粒子になることが わかった。以上の結果から, 以後の $\mathrm{BaCO}_{3}$ 粒子の生成条件の検 討は, 粒子の成長が終了する $\mathrm{pH}=7$ で行なうことにした。

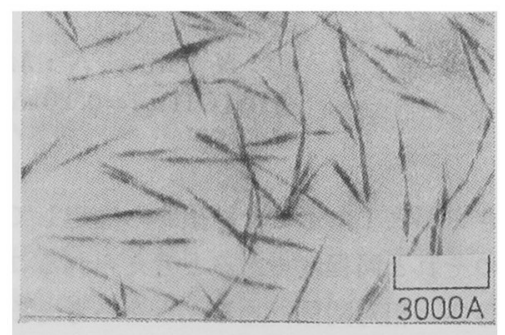

(a)

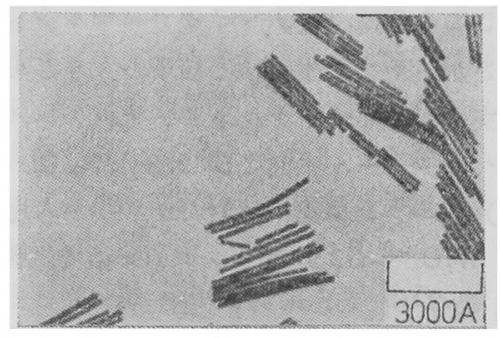

(b)

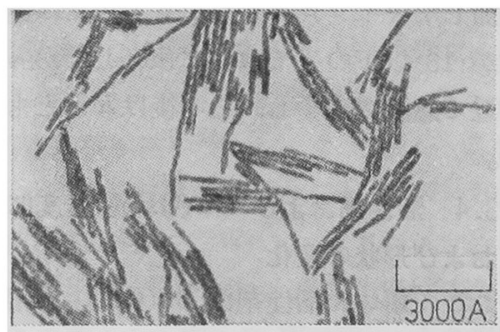

(c)

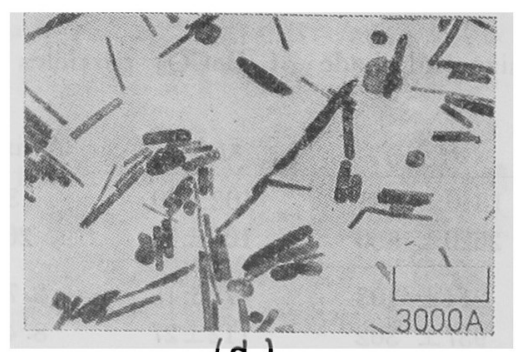

(d)

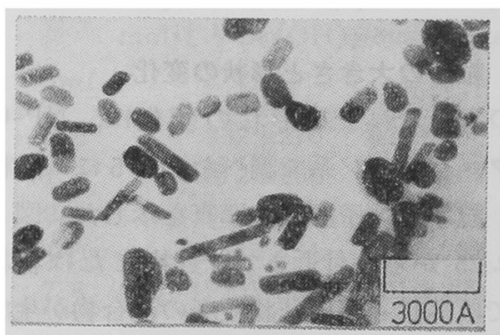

(e)

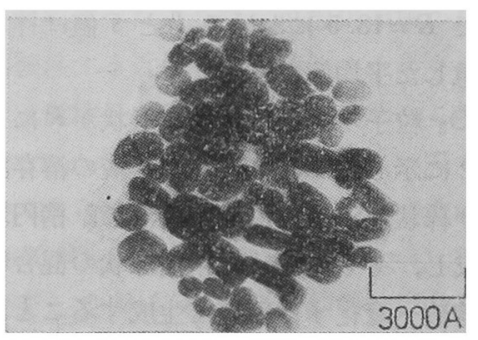

(f)

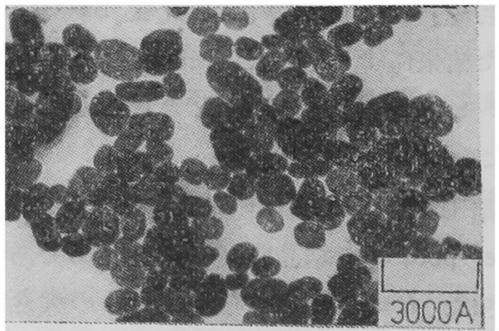

(g)

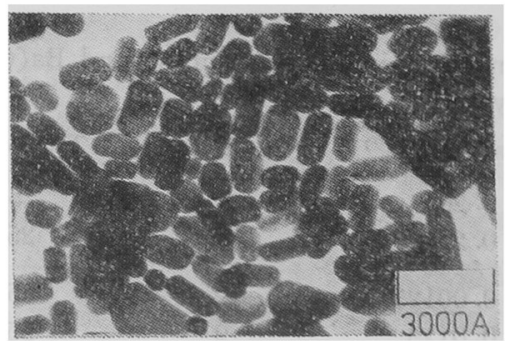

(h)

Fig. 5 Electron micrographs of $\mathrm{BaCO}_{3}$ particles prepared in various $R$, molar ratio $\left(\mathrm{H}_{2} \mathrm{O} / \mathrm{NP}-6\right)$, in $\mathrm{NP}-6 /$ cyclohexane systems at $25^{\circ} \mathrm{C}$

$R=$ (a ) ; 2.25, (b) ; 4.5, (c) ; , (d) ; 13.5, (e) ; 18, (f) ; 36, (g) ; 54, (h) ; 72 $\left[\mathrm{Ba}(\mathrm{OH})_{2}\right]=0.20 \mathrm{~mol} \cdot \mathrm{l}^{-1}[\mathrm{NP}-6]=0.10 \mathrm{~mol} \cdot \mathrm{kg}^{-1}$

40) T. M. Doscher, G. E. Myers, D. C. Atkins, Jr., J. Colloid Sci., 6, 223(1951). 
Table 2 Effect of $R$ on size and shape of $\mathrm{BaCO}_{3}$ particles prepared in $\mathrm{NP}-6 / 0.20 \mathrm{~mol} \cdot \mathrm{l}^{-1} \mathrm{Ba}(\mathrm{OH})_{2} /$ cyclohexane systemes

\begin{tabular}{lcccl}
$R^{a)}$ & $i / \AA$ & $\bar{s} / \AA$ & Axis ratio & Particle \\
\hline 2.25 & $2720 \pm 1290$ & $70 \pm 10$ & $39 \pm 18$ & Rodlike \\
4.5 & $2620 \pm 850$ & $100 \pm 15$ & $26 \pm 8.7$ & Rodlike \\
9 & $2630 \pm 1280$ & $114 \pm 22$ & $23 \pm 11$ & Rodlike \\
13.5 & $1360 \pm 713$ & $222 \pm 163$ & $6.1 \pm 3.2$ & Rodlike+ \\
18 & $1170 \pm 658$ & $585 \pm 225$ & $2.0 \pm 1.1$ & Ellipsoidal \\
36 & $1290 \pm 611$ & $770 \pm 272$ & $1.7 \pm 0.8$ & Ellipsoidal \\
54 & $1160 \pm 336$ & $799 \pm 221$ & $1.4 \pm 0.5$ & Ellipsoidal \\
72 & $1340 \pm 389$ & $806 \pm 230$ & $1.7 \pm 0.4$ & Ellipsoidal
\end{tabular}

a) $R$ : Molar ratio of $\mathrm{H}_{2} \mathrm{O}$ to $\mathrm{NP}-6$.

\section{3 $R$ による $\mathrm{BaCO}_{3}$ 粒子の大きさと形状の変化}

$R$ による $\mathrm{BaCO}_{3}$ 粒子の大ささ拈よび形状の変化は, NP-6/ $0.2 \mathrm{~mol} \cdot 1^{-1} \mathrm{Ba}(\mathrm{OH})_{2} /$ シクロヘキサン系で調べた。図 5 には, 種 々の $R$ で得られた $\mathrm{BaCO}_{3}$ 粒子の電子顕微鏡写真を示した。図 5 からわかるよらに, $\mathrm{R}=2.25$ から 9 付近までは針状または棒状 粒子が生成するが, 18 では棒状之棈円球状粒子の混合物が生成 し, それ以上の $R$ では比較的単分散性のよい棈円球状粒子のみが 生成した。表 2 には，それぞれの $R$ で得られた粒子の $\bar{l}, \bar{s}, \bar{l} / \bar{s}$ 值 および形状を示した。ここで $R=13.5$ における $\bar{l}$ と $\bar{s}$ 值は棒状 と楕円球状粒子の割合を考慮した平均值である。

このように生成する $\mathrm{BaCO}_{3}$ 粒子の大きさおよび形状がRによ って変化するが，これは図 2 に示した $\mathrm{Ba}(\mathrm{OH})_{2}$ 水溶液の溶存状 態との比較から, 針状および棒状粒子は無色透明溶液で, 棈円球 状粒子は青色透明溶液で生成し，そして棒状と棈円球状の混合粒 子は無色透明から青色透明溶液へ变化する領域で生成することが わかった。ここで無色透明溶液系で針状および棒状粒子が生成す るのは, 前に述べたように, この系の逆ミセル内の水がかなり固 定されていることから, 生成する糸状あるいは針状 $\mathrm{Ba}(\mathrm{OH})_{2} /$ $\mathrm{CO}_{2}$ /活性剂錯体に依存した結果によるものと考えられる。した がって，その大きさは逆ミセルの大きさ（表 1）と此較してみる と必ずしも一致しなかった。

一方, 青色透明溶液で棈円球状の $\mathrm{BaCO}_{3}$ 粒子が生成するのは, 水の活量が 1 に近いWater pool 中で結晶成長が進むためであろ う。しかし，粒子の大きさは， $R=18$ における逆ミセルの大きさ （表 1）とほぼ一致した。このことは, マイクロエマルションの

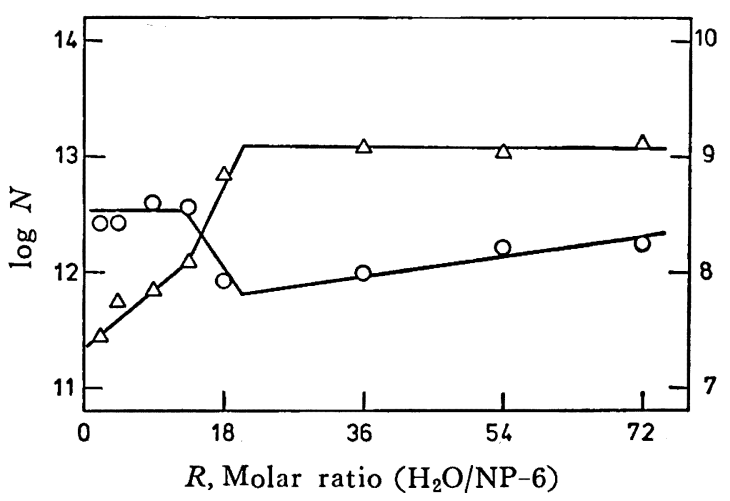

Fig. 6 Plots of $N$ and $M$ vs. $R$ in NP-6/cyclohexane systems at $25^{\circ} \mathrm{C}$

$$
\begin{aligned}
& \bigcirc: N \text { value, } \triangle: M \text { value } \\
& {\left[\mathrm{Ba}(\mathrm{OH})_{2}\right]=0.20 \mathrm{~mol} \cdot \mathrm{l}^{-1}}
\end{aligned}
$$

大ささが表 1 に示した結果から推定して， $R=18$ に拈ける逆ミセ ルのそれと同程度であると考えられること，また Water pool の 大きさと相対関係にあることから考えると、マイクロエマルショ ン相で生成する粒子の大きさは Water pool の大きさにコントロ ールされるものと考えられる。

このよらに W/O マイクロエマルション相の Water pool の大 きさが，そこで生成する粒子の大きさをコントロールするといら 事実は, ヘキサデシルトリメチルアンモニウム=ブロミド／水／ 1ーヘキサノール系および 2,2-ビス（2-エチルヘキシルカルボニ ル)-1-エタンスルホン酸のナトリウム塩/水/シクロヘキサン系 の $\mathrm{W} / \mathrm{O}$ マイクロエマルション相で調製した $\mathrm{NiB}^{28)}$ および $\mathrm{Fe}_{3}$ $\mathrm{O}_{4}$ 粒子'9)についての報告がある。

一方， $N$ およびM値の $R$ による变化は図 6 に示した。 $M$ 値は $i$ および 值（表 2）の大きさから推定されるよらに， $R$ とともに 増加してマイクロエマルション相では飽和した。しかし， $N$ 值は $R$ が 13 以下の系では $R$ に依存しなかったが，相転移する $R=18$ 付近で急激に娍少し，その後は $R$ ととも増加する傾向を示し た。

3.4 活性剤および $\mathrm{Ba}(\mathrm{OH})_{2}$ 濃度による $\mathrm{BaCO}_{3}$ 粒子の大き さおよび形状の変化

ここで用いた活性剤は $\mathrm{Ba}(\mathrm{OH})_{2}$ 水溶液に対して可溶化能が小 さいため, $\mathrm{BaCO}_{3}$ の調製は $\mathrm{NP}-6 /$ シクロへキサン系 $(R=4.5)$

Table 3 Effect of concentration of surfactant and $\mathrm{Ba}(\mathrm{OH})_{2}$ on size and shade of $\mathrm{BaCO}_{3}$ particles prepared in $\mathrm{NP}-6 /$ cyclohexane systems

\begin{tabular}{ccccrrrr}
{$[\mathrm{NP}-6]^{a)}$} & {$\left[\mathrm{Ba}(\mathrm{OH})_{2}\right]^{b)}$} & $R^{c)}$ & Temp. $/{ }^{\circ} \mathrm{C}$ & $\bar{l} / \AA$ & $\bar{s} / \AA$ & Axis ratio & Particle \\
\hline 0.75 & 0.20 & 4.5 & 25 & $1340 \pm 688$ & $102 \pm 20$ & $13 \pm 6.9$ & Rodlike \\
0.10 & 0.20 & 4.5 & 25 & $2620 \pm 850$ & $100 \pm 15$ & $26 \pm 8.7$ & Rodlike \\
0.10 & 0.00125 & 9 & 55 & $214 \pm 103$ & $78 \pm 15$ & $2.7 \pm 1.4$ \\
0.10 & 0.0125 & 9 & 55 & $937 \pm 362$ & $112 \pm 27$ & $8.4 \pm 3.2$ & Rodlike \\
0.10 & 0.05 & 9 & 55 & $2380 \pm 818$ & $164 \pm 26$ & $15 \pm 4.5$ \\
0.10 & 0.10 & 9 & 55 & $3330 \pm 1140$ & $181 \pm 37$ & $18 \pm 6.7$ \\
0.10 & 0.20 & 9 & 55 & $2260 \pm 1040$ & $126 \pm 51$ & $18 \pm 8.2$ & Rodlike \\
0.10 & 0.80 & 9 & 55 & $646 \pm 280$ & $116 \pm 41$ & $5.6 \pm 2.4$ & Rodlike
\end{tabular}

a) $[\mathrm{NP}-6]: \mathrm{mol} \cdot \mathrm{kg}^{-1}$.

b) $\left[\mathrm{Ba}(\mathrm{OH})_{2}\right]: \mathrm{mol} \cdot \mathrm{l}^{-1}$.

c) $R$ : Molar ratio of $\mathrm{H}_{2} \mathrm{O}$ to $\mathrm{NP}-6$. 


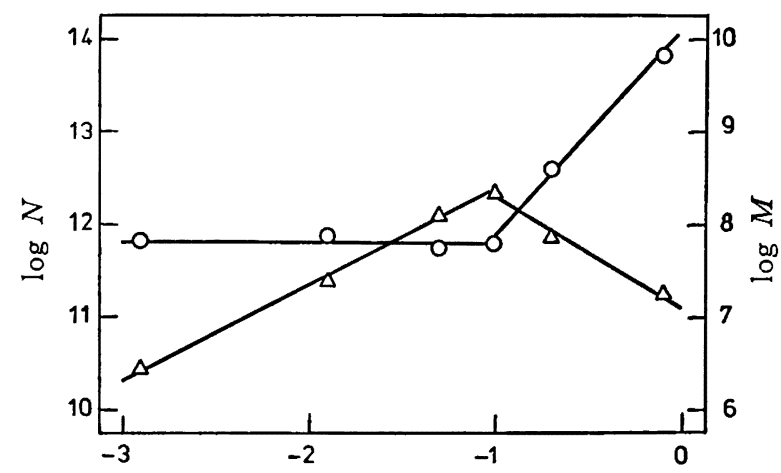

$\log C$

Fig. 7 Plots of $N$ and $M$ vs. concentrations of $\mathrm{Ba}(\mathrm{OH})_{2}$ in $\mathrm{NP}-6 /$ cyclohexane systems at $55^{\circ} \mathrm{C}$

$$
\begin{gathered}
O: N \text { value, } \triangle: M \text { value } \\
R=9,[\mathrm{NP}-6]=0.10 \mathrm{~mol} \cdot \mathrm{kg}^{-1}
\end{gathered}
$$

で 0.075 と $0.10 \mathrm{~mol} \cdot \mathrm{kg}^{-1}$ の二点でしか行ならことができなか っだ。一方, $\mathrm{Ba}(\mathrm{OH})_{2}$ 濃度については $\mathrm{Ba}(\mathrm{OH})^{2}$ の水への溶解 度が小さいことから，調製温度を $55^{\circ} \mathrm{C}$ とし，NP-6/シクロへキ サン系 $(R=9)$ で 0.00125 から $0.80 \mathrm{~mol} \cdot l^{-1}$ の範囲で行なっ た。表 3 には，それぞれの系で得られた $\mathrm{BaCO}_{3}$ 粒子の $\bar{l}, \bar{s}, \bar{l} / \bar{s}$ 值および形状を示した。表 3 から，活性剤濃度による粒子の形状 はいずれも棒状であったが，その大きさは $l$ および から見積ると高濃度ほど大きい。一方， $\mathrm{Ba}(\mathrm{OH})_{2}$ 濃度による変 化については粒子の形状はどの濃度においても同様に棒状であっ たが．その大きさは $\bar{l}$ および $\bar{s}$ 值の大きさから $0.10 \mathrm{~mol} \cdot l^{-1}$ ま で濃度とともに増大し，その後は減少する傾向を示した。また $\bar{l} / \bar{s}$ 值から低濃度と高濃度で非常に小さな粒子が生成することが わかった。

ここで低濃度で小さな粒子が生成するのは， $\bar{l}$ おび $\bar{s}$ 值の Ba $(\mathrm{OH})_{2}$ 濃度依存性から理解することができるが，高濃度でふた たび小さい粒子が生成するのは注目すべきことである。これは $\mathrm{Ba}(\mathrm{OH})_{2}$ 濃度とともに可溶化量が減少 ${ }^{36)}$ し，ここで用いた系 $(R$ =9）がマクロエマルションヘ相転移する可溶化限界点 $(R=10)$ に近づくため, 溶液は青色透明となって W/O マイクロェマルシ ョン相を形成し，粒子がその相の Water pool 中で生成するため であると考えられる。ここで逆ミセル内への Water pool の形成 は, また $\mathrm{Ba}(\mathrm{OH})_{2}$ の塩析効果によっても促進されるだろら。こ のように, W/O マイクロェマルション相で小さな粒子が生成す ることは，すでに表 2 に示した $R$ にる粒子の大きさの変化から もわかる。

以上の結果はまた図 7 に示した $M$ および $N$ 值の $\mathrm{Ba}(\mathrm{OH})_{2}$ 濃度 変化からも説明されよう。すなわち, 多くの難溶珄塩の結晶成長 に怙いていわれているように，低濃度で粒子の大きさ（M值）が $\mathrm{Ba}(\mathrm{OH})_{2}$ 濃度とともに增大するのは結晶核が発生したのち，個 々の粒子の成長時間が長くなり，結晶成長反応が支配的になるた めであろう。一方, 高濃度領域で $\mathrm{Ba}(\mathrm{OH})_{2}$ 濃度とともに粒子の 大きさが減少するのは，急速に結晶核の数が増加し，核発生が結 晶成長に優先するためであろう。このことは，また $N$ 值が低濃度 領域で一定值を示し, 高箼度領域ではある濃度から急激に増加す るといら結果からも理解できよう。
Table 4 Effect of temperatures on size and shape of $\mathrm{BaCO}_{3}$ particles prepared in $\mathrm{NP}-4 / 0.20 \mathrm{~mol} \cdot \mathrm{l}^{-1}$ $\mathrm{Ba}(\mathrm{OH})_{2}$ /"isooctane" systems

\begin{tabular}{crrcl} 
Temp. $/{ }^{\circ} \mathrm{C}$ & \multicolumn{1}{c}{$\bar{l} / \AA$} & $\bar{s} / \AA$ & Axis ratio & Particle \\
\hline 55 & $831 \pm 450$ & $194 \pm 43$ & $4.3 \pm 2.3$ & Rodlike \\
40 & $3800 \pm 2430$ & $106 \pm 28$ & $26 \pm 23$ & Rodlike \\
25 & $2780 \pm 2780$ & $130 \pm 39$ & $21 \pm 22$ & Rodlike \\
10 & $2840 \pm 2340$ & $102 \pm 20$ & $28 \pm 23$ & Rodlike \\
0 & $2250 \pm 1090$ & $94 \pm 31$ & $24 \pm 12$ & Rodlike \\
-10 & $2080 \pm 2270$ & $112 \pm 50$ & $19 \pm 20$ & Rodlike \\
-20 & $764 \pm 401$ & $161 \pm 32$ & $4.7 \pm 2.5$ & Rodlike
\end{tabular}

Table 5 Effect of bubbling velocity of $\mathrm{CO}_{2}$ on size and shape of $\mathrm{BaCO}_{3}$ particles prepared in NP-6/0.20 $\mathrm{mol} \cdot l^{-1} \mathrm{Ba}(\mathrm{OH})_{2} /$ cyclohexane systems

\begin{tabular}{lrrrl}
$V / \mathrm{m} l \cdot \mathrm{s}^{-1}$ & \multicolumn{1}{c}{$\bar{l} / \AA$} & $\bar{s} / \AA$ & Axis ratio & Particle \\
\hline 0.5 & $832 \pm 270$ & $622 \pm 200$ & $1.3 \pm 0.4$ & Ellipsoidal \\
1.0 & $872 \pm 232$ & $628 \pm 163$ & $1.4 \pm 0.4$ & Ellipsoidal \\
2.0 & $984 \pm 331$ & $685 \pm 216$ & $1.4 \pm 0.5$ & Ellipsoidal \\
4.0 & $1044 \pm 454$ & $685 \pm 293$ & $1.5 \pm 0.7$ & Ellipsoidal \\
7.5 & $1220 \pm 356$ & $901 \pm 269$ & $1.4 \pm 0.4$ & Ellipsoidal
\end{tabular}

\section{5 温度による $\mathrm{BaCO}_{3}$ 粒子の大きさおよび形状の変化}

前に述べたように, 可溶化領域からマクロエマルション領域へ 相転移する近傍では W/O マイクロエマルションが形成し，そこ では微粒子が生成した。しかし，この転移はまた図 2 からわかる ように，温度を変えることによっても実現できることから，ここ ではさらにこのことを明らかにするために, NP-4/0.20 mol-l-1 $\mathrm{Ba}(\mathrm{OH})_{2} /$ イソォクタン系 $(R=4)$ で盜度を $-20^{\circ} \mathrm{C}$ から $55^{\circ} \mathrm{C}$ ま で変えて $\mathrm{BaCO}_{3}$ 粒子の調製を行なった。またこの調製は無機反 応を $0^{\circ} \mathrm{C}$ 以下の水中で行ならといら点でも興味がある。予想され るように，W/O マイクロエマルションはここで用いた系 $(R=4)$ が相転移する可溶化限界点に近い温度，すなわち， $-20^{\circ} \mathrm{C}$ と 55 ${ }^{\circ} \mathrm{C}$ (それぞれの温度での可溶化限界点は $R=5.5$ と 4.7 である) で生成し，それら両温度で微粒子が生成（表 4) することがわか る。

$3.6 \mathrm{CO}_{2}$ の吹き込み速度による $\mathrm{BaCO}_{3}$ 粒子の大きさおよび 形状の変化

一般に，水溶液に拈ける沈殿反応によって粒子が生成する場 合，急速に生成反応を進め，多くの結晶核を発生させて，核の成 長および熟成による粒子成長を抑制すると，微粒子が生成すると いわれている。そこで, 本研究の W/O マイクロエマルション相 でも同様なことが期待できるかを確かめるために，NP-6/0.20 $\mathrm{mol} \cdot l^{-1} \mathrm{Ba}(\mathrm{OH})_{2} /$ シクロヘキサン系 $(R=72)$ で $\mathrm{CO}_{2}$ の吹き込 み速度を変えて $\mathrm{BaCO}_{3}$ 粒子の調製を行なった。得られた結果を 表 5 に示した。生成した粒子はどの速度においても棈円球状であ ったが，その大きさは予想に反して速度の増加とともに増大し た。この違いについては，現在まだ明らかでないが，一つの原因 として W/O マイクロェマルション相での $\mathrm{BaCO}_{3}$ 粒子の生成速 度が水相に扟けるより 4 倍（図 3）も速いため，たと之吹き込み 速度の大きい系で多量の核が発生しても，核から粒子への成長が 優先した結果, $\mathrm{CO}_{2}$ の吹さ込及速度とともに大きな粒子が生成 したものと考学られる。したがって，M值は表 5 から推定される ように, $\mathrm{CO}_{2}$ の吹き込み速度とともに減少し， $N$ 值は式(4)， 
（5）から推定されるように逆に増大した。 （1983 年 10 月，日本化学会コロイドおよび界面化学討論会発

本研究の費用は，文部省科学研究費特定研究「分子集合体の高 表）

次組織と機能」によっている。

\title{
Special Articles on \\ Chemistry of Fine Particles and Applications
}

Preparation of $\mathrm{BaCO}_{3}$ Fine Particles in W/O Microemulsion

\author{
Kijiro Kon-no*, Misao Korde and Ayao Kitahara \\ Department of Industrial Chemistry, Institute of Surface and Colloid \\ Chemistry, Science University of Tokyo ; Kagurazaka, \\ Shinjuku-ku, Tokyo 162 Japan
}

By utilizing $\mathrm{W} / \mathrm{O}$ microemulsion phase, $\mathrm{BaCO}_{3}$ fine particles were prepared by bubbling of $\mathrm{CO}_{2}$ into poly (oxyethyene ether) nonionic surfactant/aqueous $\mathrm{Ba}(\mathrm{OH})_{2}$ solution/cyclohexane or "isooctane" systems under various conditions. Particles of a different size and shape were formed in the fifferent solubility regions of $\mathrm{Ba}(\mathrm{OH})_{2}$ in surfactant solutions, i.e., in the colorless solution, rodlike particles having axis ratio of $c a .23 \sim 39$ were formed, whereas monodisperse ellipsoidal particles were formed in the blue translucent of (Figs. 2 and 3, Table 2). This difference could be explained in relation with the formation of $\mathrm{W} / \mathrm{O}$ microemulsion phase. The size of particles formed in the $\mathrm{W} / \mathrm{O}$ microemulsion phase was controlled by the size of water pool therein. This was also indicated from the change in the size and shape of particles with concentration of $\mathrm{Ba}(\mathrm{OH})_{2}$ and with temperature (Tables 3 and 4). The formation and growth proceses of the particles in $\mathrm{W} / \mathrm{O}$ microemulsion phase were also discussed from the electron micrographs of particles formed by bubbling of different amounts of $\mathrm{CO}_{2}$ (Fig. 4). 